\title{
COMPARISON OF HANDWRITING LEGIBILITY FOR MANUAL HANDWRITING AMONG TYPICALLY DEVELOPING INDIAN CHILDREN
}

\author{
Dr. Sushmita Ahirwal ${ }^{1}$, Dr. Anita Gupta ${ }^{2}$, Dr. Sheetal Gupta ${ }^{3}$ \\ ${ }^{1}$ Assistant Professor, Department of Occupational Therapy, Mahatma Gandhi Occupational Therapy \\ College, Jaipur \\ ${ }^{2}$ Lecturer and Head, Department of Occupational Therapy, All India Institute of Physical Medicine \\ and Rehabilitation, Mumbai
}

${ }^{3}$ Clinical Occupational Therapist, LTMGH, Sion Hospital, Mumbai

Article DOI: $\underline{\text { https://doi.org/10.36713/epra8427 }}$ DOI No: 10.36713/epra8427

\begin{abstract}
Handwriting involves the integration of many skills, including perceptual motor skills, motor planning and cognition visual motor skills, as well as control of kinesthetic and tactile abilities to grasp and maintain control of the writing tool, as well as motor control The aim of this study was to compare the handwriting skills of typically developing Indian children on ETCH-M (Evaluation Tool Of Children Handwriting - Manuscript). A sample of 200 typically developing Indian children were included in the study using convenience sampling method. The age ranged from 6 years to 9 years. It was found that ETCH-M is an assessment tool which can assess the Handwriting skills of Indian typically developing children in 6-9 years of age group. Independent sample t- test was done to compare the mean raw score of each group. There was a significant difference with statistical value of $p<0.001$. The handwriting evaluation depends upon six characteristics of writing: Handwriting legibility, letter formation, uniformity of letter size, uniformity of letter slant, spacing between letters and words, alignment of lines of writing.
\end{abstract}

KEYWORDS: Handwriting, legibility, occupational therapy, vernacular medium.

\section{Need of the study}

Intervention for handwriting issues is done by pediatric Occupational therapists. Using a standardized tool enables objectivity and accuracy in rating the performance. Evaluation tool of children's handwriting (ETCH) is one such standardized tool used in assessment of handwriting skills in children. The tool uses English manuscripts and cursive writing tasks. However in Indian scenario, children study in English medium and non-English medium schools. In clinical practice too, children with handwriting issues come from varied background that is English, Hindi, Marathi, Urdu, etc. Therefore using a tool like Evaluation Tool of Children's Handwriting which is standardized on children who have come from English medium, may not give a good judgment of their Handwriting skills. This study is undertaken to find whether non English medium (Marathi/Hindi) children have comparable handwriting skills as that of English medium school children when tested on Evaluation tool of Children's Handwriting. The script of both the languages, Hindi and Marathi is same which is known as "Devanagri". Hence this study compares English medium children with Marathi/Hindi medium children. 


\section{EPRA International Journal of Research and Development (IJRD)}

Volume: 6 | Issue: 9 | September 2021
- Peer Reviewed Journal

\section{INTRODUCTION}

Handwriting involves the integration of many skills, including perceptual motor skills, motor planning and cognition visual motor skills, , as well as control of kinesthetic and tactile abilities to grasp and maintain control of the writing tool, as well as motor control ${ }^{(1)}$.

\section{Why handwriting is important?}

There are various reasons why handwriting is important and responsible in academic performance. Though today's elementary schools are increasingly influenced by technologies such as tablets and computers, but still students need to write on paper up to 25 to $60 \%$ of their classroom activities up to grades 5.15 to $22 \%$ of time technology such as computers, tablets, interactive whiteboard etc. this facility is not yet available in countries like India. Handwriting is an important skill that need to be developed first and will influence student's writing, reading, language use and critical thinking. Handwriting influence students to perform better and more efficiently the hierarchy of skills required in other subjects, score better grades, better test scores, and better academic performance. ${ }^{(2)}$

Griffin (1998) defines the following skills should be able to complete by kindergarten students are:

1. Independently write many lowercase and uppercase. 2. Use phonemic and letters knowledge awareness to spell independently. 3. Write to express own meaning of alphabet and letters. 4. Have to write own name and first name of parents and some friends of classmates. 5. Write most alphabet, some words and numbers when they are dictated.

The ability to write own name and first name of friends and parents is an important indicator of early literacy. The National Early Literacy Panel (NELP; 2008) Identified name writing as an important indicator related to later reading ability. Name writing based on alphabetic principal (example specific letters correspond to specific letters sound).

Weinberger (1996) found those children's skills of writing their name at five years was linked to their reading skills at 7 years of age. ${ }^{(3)}$

The handwriting evaluation depends upon six characteristics of writing: Handwriting legibility, letter formation, uniformity of letter size, uniformity of letter slant, spacing between letters and words, Alignment of lines of writing. ${ }^{(4)}$

Children with handwriting difficulties are mainly referred to occupational therapists and form an important part of the community or school-based occupational therapists domain. Therapists use a comprehensive approach to handwriting evaluation that includes arrangement of handwriting tasks necessary for day-to-day functioning in the class.

\section{METHODOLOGY}

- An analytical, observational and comparative study was conducted evaluating ETCH-M in normal children. Samples of 200 children were recruited after conducting pilot study. Convenience sampling technique was used for a period of 18 months in Occupational therapy department of the institute and schools in Mumbai. The inclusion criteria of the study were 1. Ability to write in English. (At least six months of experience in writing in English). 2. Children who are studying in English medium school or non-English medium (vernacular) school. 3. Either gender. 4. Age group- 6 to 9 years. The Exclusion criteria were Children with: 1. any developmental disability with or without associated structural abnormality in child's hand which is used for writing. 2. Visual and hearing impairment.

\section{THE EVALUATION TOOL OF CHILDREN'S HANDWRITING (ETCH)}

- The Evaluation Tool of Children's Handwriting $(\mathrm{ETCH})$ was designed to evaluate manuscript and cursive handwriting skills of Grades 1 through 6 who are experiencing difficulty with written communication. The primary focus of the ETCH is to assess a child's legibility and speed of handwriting in writing tasks that are similar to those required of students in the classroom. The ETCH may be administered to any child who is experiencing handwriting problems.

The seven tasks of the ETCH-Manuscript (ETCH-M) measure the following manuscript writing tasks: Task 1 Writing Alphabet from Memory, Task 2 Writing Numerals from memory, Task 3 Near-point Copying, Task 4 Far point copying, Task 5 Dictation, Task 6 Sentence composition

The ETCH-cursive segment (ETCH-C), consists of the same task include Manuscript to cursive transition task. The examiner should allot approximately 20 to 25 minutes to administer the ETCH to a child with handwriting problems. Scoring requires approximately 10 to 20 minutes. 


\section{EPRA International Journal of Research and Development (IJRD)}

Volume: 6 | Issue: 9 | September 2021
- Peer Reviewed Journal

\section{STUDY PROCEDURE}

After obtaining the approval from IRB of the institute the study was conducted on age group 6-9 years. A total number of 200 children who fulfill the inclusion criteria will be taken for the study. Among them 100 children from non- English (vernacular) medium school children and 100 children from English medium school children will be taken. A demographic questionnaire was used to gather relevant background data about the children to determine which children meets the study inclusion criteria. Children was be enrolled with parent's consent of the child and assent from children self. The selected subject's handwriting was evaluated on Evaluation Tool of Children's Handwriting (ETCHM). After administering the test, score was analyzed using statistical test. The session comprised of 45-50 minutes approximately. All selected children handwriting was evaluated using evaluation tools of children's handwriting-manuscripts (ETCH-M).
After administering test the score was analyzed using statistical test.

\section{RESULTS AND TABLES}

The data was entered using MS-Excel-2007 and analyzed using SPSS-16 software. An observational analysis for numerical data consists of mean with standard deviation (SD) and for categorical data consists of frequencies \& percentage for various parameters. An independent sample test $\mathrm{t}$ was used in this study. The $p$ value less than 0.05 were taken as statistically significant. It is observed from the below table no. 1 when the study participants were divided by age, 22 from English medium and 23 from vernacular medium were 6 years old, 25 each from English medium vernacular medium were 7 years old, 30 each from English medium and 31 from vernacular medium were 8 years old while 23 from English medium and 21 from vernacular medium were 9 years old.

The mean age of the study participants was 7.5 years with a standard deviation of 1.07 years Table 1: Distribution of the study participants as per their age.

\begin{tabular}{|c|c|c|c|}
\hline $\begin{array}{c}\text { Age } \\
\text { (in years) }\end{array}$ & English & $\begin{array}{c}\text { Vernacular } \\
\text { (Hindi+Marathi) }\end{array}$ & Total \\
\hline $\mathbf{6}$ & 22 & 23 & 45 \\
\hline $\mathbf{7}$ & 25 & 25 & 50 \\
\hline $\mathbf{8}$ & 30 & 31 & 61 \\
\hline $\mathbf{9}$ & 23 & 21 & 44 \\
\hline Total & 100 & 100 & 200 \\
\hline
\end{tabular}

Figure 1: Distribution of the Study Participants as per Their Age.

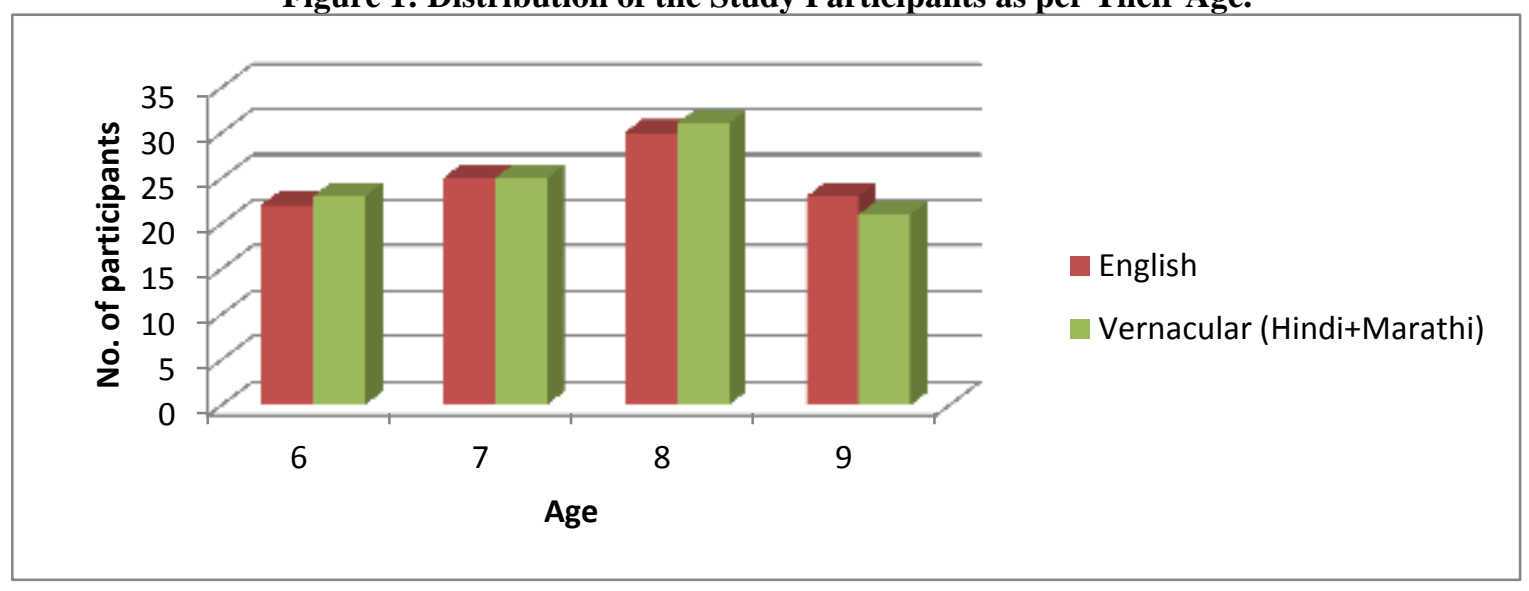




\section{EPRA International Journal of Research and Development (IJRD)}

Volume: 6 | Issue: 9 | September 2021

- Peer Reviewed Journal

Table 2: Distribution of the Study Participants as per their Education Medium.

\begin{tabular}{|c|c|c|}
\hline Medium & $\begin{array}{c}\text { No. of } \\
\text { participants }\end{array}$ & Percent \\
\hline English & 100 & 50.0 \\
\hline Hindi & 50 & 25.0 \\
\hline Marathi & 50 & 25.0 \\
\hline Total & 200 & 100.0 \\
\hline
\end{tabular}

Figure 2: Distribution of the study participants as per their education medium.

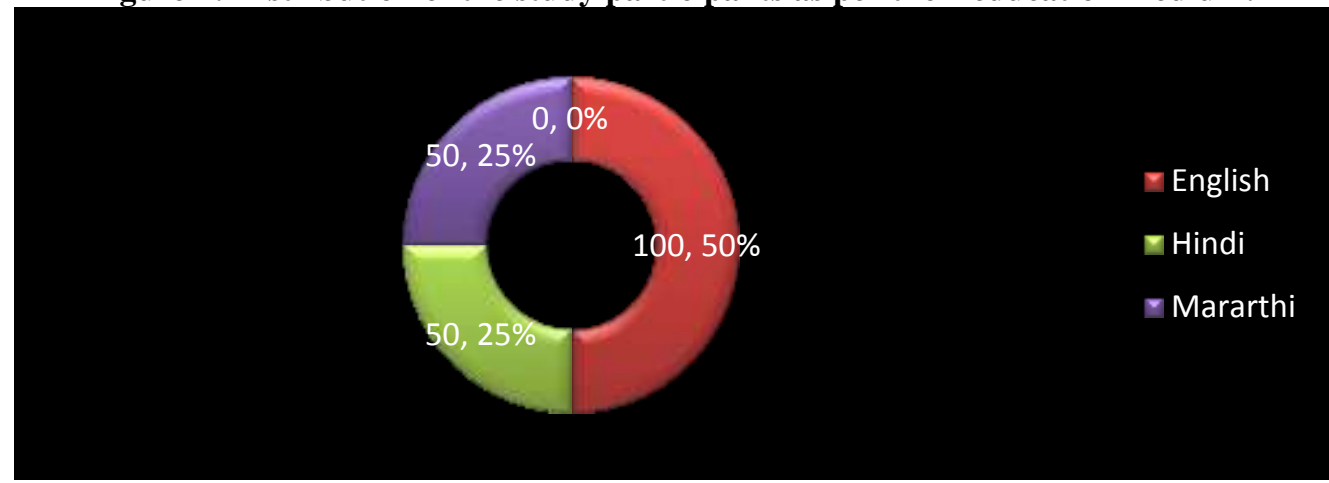

In the below table we compare the hand writing legibility of the study participants of English medium based on their ages.

Table 3: Comparison of hand writing legibility of participants belonging to English medium based on medium of their age.

\begin{tabular}{|c|c|c|c|c|}
\hline \multirow[b]{2}{*}{$\begin{array}{c}\text { Age } \\
\text { (inyrs) }\end{array}$} & \multicolumn{4}{|c|}{ TOTAL LEGIBILITY SCORE } \\
\hline & & Words & Letters & Numbers \\
\hline \multirow[t]{4}{*}{$\begin{array}{c}6 \\
(N=22)\end{array}$} & Mean & 80.805 & 84.895 & 97.714 \\
\hline & Median & 89.500 & 89.000 & 100.000 \\
\hline & Std. Deviation & 21.3441 & 13.2152 & 5.2782 \\
\hline & Min-Max & $17.0-100.0$ & $47.0-100.0$ & $82.3-100.0$ \\
\hline \multirow[t]{4}{*}{$\begin{array}{c}7 \\
(\mathrm{~N}=25) \\
\end{array}$} & Mean & 86.680 & 89.560 & 97.240 \\
\hline & Median & 92.000 & 93.000 & 100.000 \\
\hline & Std. Deviation & 14.8849 & 9.6828 & 5.4565 \\
\hline & Min-Max & $41.0-100.0$ & $64.0-100.0$ & $82.0-100.0$ \\
\hline \multirow[t]{4}{*}{$\begin{array}{c}8 \\
(N=30)\end{array}$} & Mean & 81.400 & 86.633 & 98.600 \\
\hline & Median & 89.000 & 89.500 & 100.000 \\
\hline & Std. Deviation & 17.1154 & 12.3358 & 3.3280 \\
\hline & Min-Max & $25.0-100.0$ & $35.0-100.0$ & $88.0-100.0$ \\
\hline \multirow[t]{4}{*}{$\begin{array}{c}9 \\
(\mathrm{~N}=23)\end{array}$} & Mean & 85.652 & 85.278 & 94.304 \\
\hline & Median & 88.000 & 93.000 & 100.000 \\
\hline & Std. Deviation & 14.4115 & 19.6262 & 14.5647 \\
\hline & Min-Max & $50.0-100.0$ & $13.0-100.0$ & $32.0-100.0$ \\
\hline
\end{tabular}

(c) 2021 EPRA IJRD | Journal DOI: https://doi.org/10.36713/epra2016 | www.eprajournals.com |106 | 


\section{EPRA International Journal of Research and Development (IJRD)}

In the below table we compare the hand writing legibility of the study participants of non- English medium based on their ages.

Table 4: Comparison of hand writing legibility of participants belonging to non- English medium based on medium of their age.

\begin{tabular}{|c|c|c|c|c|}
\hline \multirow[b]{2}{*}{$\begin{array}{c}\text { Age } \\
\text { (inyrs) }\end{array}$} & \multicolumn{4}{|c|}{ TOTAL LEGIBILITY SCORE } \\
\hline & & Words & Letters & Numbers \\
\hline \multirow[t]{4}{*}{$\begin{array}{c}6 \\
(\mathrm{~N}=23) \\
\end{array}$} & Mean & 80.77 & 83.75 & 95.19 \\
\hline & Median & 88.00 & 88.70 & 100.00 \\
\hline & Std. Deviation & 18.69 & 14.47 & 8.46 \\
\hline & Min-Max & $17.00-100.00$ & $35.00-100.00$ & $59.00-100.00$ \\
\hline \multirow[t]{4}{*}{$\begin{array}{c}7 \\
(\mathrm{~N}=25) \\
\end{array}$} & Mean & 82.69 & 84.25 & 92.69 \\
\hline & Median & 88.00 & 90.00 & 100.00 \\
\hline & Std. Deviation & 19.18 & 17.47 & 16.24 \\
\hline & Min-Max & $0.00-100.00$ & $0.00-100.00$ & $0.00-100.00$ \\
\hline \multirow[t]{4}{*}{$\begin{array}{c}8 \\
(\mathrm{~N}=31) \\
\end{array}$} & Mean & 81.86 & 84.10 & 93.48 \\
\hline & Median & 88.00 & 90.00 & 100.00 \\
\hline & Std. Deviation & 19.21 & 18.19 & 16.78 \\
\hline & Min-Max & $0.00-100.00$ & $0.00-100.00$ & $0.00-100.00$ \\
\hline \multirow[t]{4}{*}{$\begin{array}{c}9 \\
(\mathrm{~N}=21)\end{array}$} & Mean & 83.80 & 83.51 & 93.25 \\
\hline & Median & 88.00 & 92.00 & 100.00 \\
\hline & Std. Deviation & 19.02 & 20.92 & 18.74 \\
\hline & Min-Max & $0.00-100.00$ & $0.00-100.00$ & $0.00-100.00$ \\
\hline
\end{tabular}

In the below table an independent sample t test shows that there is a significant difference in total legibility score L and total legibility score $\mathrm{N}$ between English and vernacular medium studentswhile there is no significant difference in total legibility score w between English and vernacular medium students. 


\section{EPRA International Journal of Research and Development (IJRD)}

Table 5: Comparison of hand writing legibility of study participants based on medium of their education

\begin{tabular}{|c|c|c|c|c|c|c|c|c|c|}
\hline $\begin{array}{c}\text { Total } \\
\text { Legibility } \\
\text { Score }\end{array}$ & Medium & Mean & $\begin{array}{c}\text { Std. } \\
\text { Deviation }\end{array}$ & $\begin{array}{l}\text { Std. } \\
\text { Error } \\
\text { Mean }\end{array}$ & $\begin{array}{c}\text { Mean } \\
\text { Difference }\end{array}$ & $\begin{array}{l}\text { Std. Error } \\
\text { Difference }\end{array}$ & $\mathbf{T}$ & $\begin{array}{c}\text { Df } \\
(\mathrm{N}-2)\end{array}$ & $\begin{array}{c}\text { Significance } \\
\text { Status } \\
\text { (2-tailed) }\end{array}$ \\
\hline \multirow[b]{2}{*}{$\mathbf{W}$} & $\begin{array}{l}\begin{array}{l}\text { English } \\
(\mathrm{N}=100)\end{array} \\
\end{array}$ & 83.5 & 16.9 & 1.69 & \multirow[b]{2}{*}{2.63} & \multirow[b]{2}{*}{2.67} & \multirow[b]{2}{*}{0.98} & \multirow[b]{2}{*}{198} & \multirow[b]{2}{*}{$\begin{array}{c}0.32 \\
\text { Not Significant }\end{array}$} \\
\hline & $\begin{array}{c}\text { Non- } \\
\text { English } \\
(\mathbf{N}=100)\end{array}$ & 80.9 & 20.68 & 2.06 & & & & & \\
\hline \multirow[b]{2}{*}{$\mathbf{L}$} & $\begin{array}{l}\text { English } \\
(\mathrm{N}=100)\end{array}$ & 86.6 & 13.89 & 1.39 & \multirow[b]{2}{*}{5.48} & \multirow[b]{2}{*}{2.48} & \multirow[b]{2}{*}{2.20} & \multirow[b]{2}{*}{198} & \multirow[b]{2}{*}{$\begin{array}{c}0.02 \\
\text { Significant }\end{array}$} \\
\hline & $\begin{array}{c}\text { Non- } \\
\text { English } \\
(\mathbf{N}=100)\end{array}$ & 81.1 & 20.65 & 2.06 & & & & & \\
\hline \multirow[b]{2}{*}{$\mathbf{N}$} & $\begin{array}{l}\text { English } \\
(\mathrm{N}=100)\end{array}$ & 97.0 & 8.13 & 0.81 & \multirow[b]{2}{*}{6.91} & \multirow[b]{2}{*}{2.15} & \multirow[b]{2}{*}{3.21} & \multirow[b]{2}{*}{198} & \multirow[b]{2}{*}{$\begin{array}{c}0.00 \\
\text { Significant }\end{array}$} \\
\hline & $\begin{array}{l}\text { Non- } \\
\text { English } \\
\text { (N=100) }\end{array}$ & 90.1 & 19.91 & 1.99 & & & & & \\
\hline
\end{tabular}

Figure 3: Comparison of hand writing total legibility of study participants based on medium of their education.

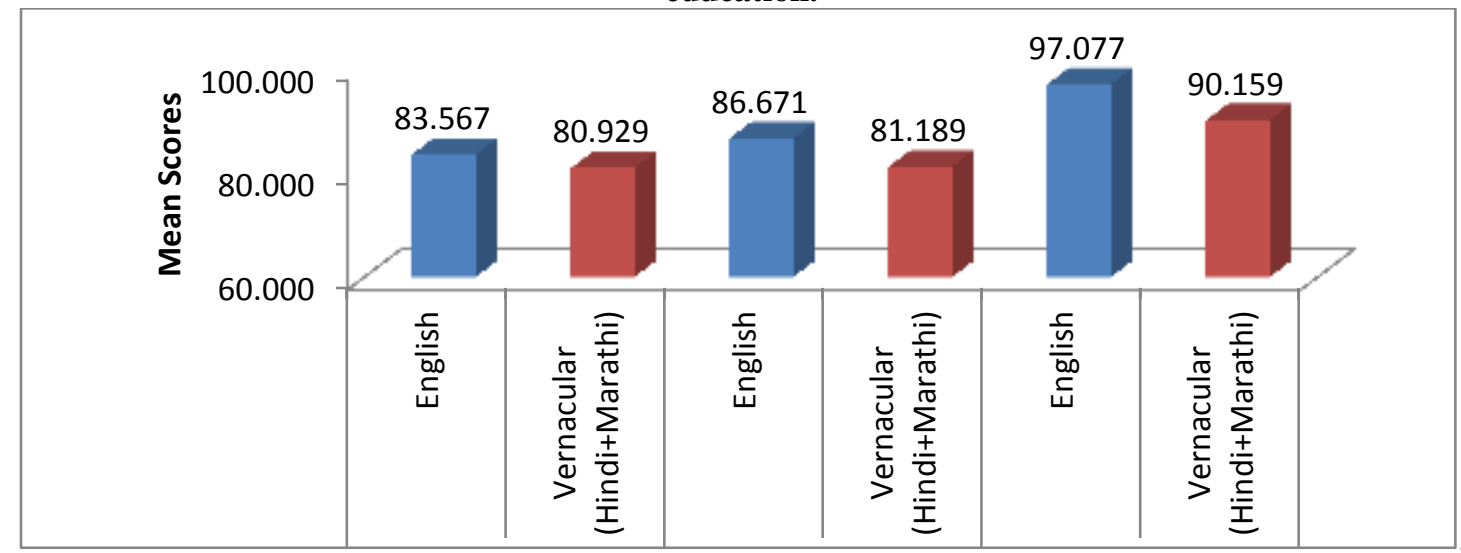

\section{DISCUSSION}

A sample of 200 children was collected in all for this study. There were equal number of children from both English and Non-English vernacular) medium (100 children). In English medium group English medium children were taken and in Non-English medium group Hindi and Marathi medium children were taken. The medium was restricted to Hindi and Marathi, as these were the samples available conveniently while conducting the pilot study, other mediums were difficult to find and were therefore, not included in the study. Apart from meeting the other criteria for inclusion, these children met the inclusion criteria of age between 6-9 years for this study. 


\section{SJIF Impact Factor 2021: 8.013| ISI I.F.Value:1.241| Journal DOI: 10.36713/epra2016 ISSN: 2455-7838(Online) EPRA International Journal of Research and Development (IJRD)}

The male children were more than female children in this study i.e. 115 males and 85 females. This sample was pre dominantly collected from children who reported to Occupational Therapy department and were studying in Brihanmumbai Municipal Corporation (BMC) schools, accompanying their siblings who were under treatment here.

The ETCH- manuscript writing section of the tool was used in this study. As it took into account assessment of children from Non-English (vernacular) medium, it was found necessary to use the manuscript writing as children from this medium may not have the ability to write in cursive, especially the younger age group.

As seen in table no. 3 was to compare age-wise handwriting legibility in children from English medium.According to findings from this study, for English medium children, the 7 year old children performs better than all three age that is 6,8 , and 9 in word and letter legibility. The mean of 6 year old children total word legibility is 80.805 , for letter 84.895 and for numeral 97.7. The mean of 7 year old children, total word legibility is 86.680 , for letter 89.560 and for numeral 97.240. For 8 year old children the mean of total word legibility is 81.4 , for letter 86.63 , and for numeral 98.60. For 9 year old children the mean of total word legibility is 85.652 , for letter 85.278 and for numeral 94.304. For numeral legibility 8 year group performed better than all group.

As seen in table no. 4 for non- English medium; the all age groups that are $6,7,8$, and 9 have performed similarly. Mean of total word legibility is 80.77 , for letter 83.75 and for numeral 95.19 of 6 year old children. The mean of 7 year old children, total word legibility is 82.69 , for letter 84.25 and for numeral 92.69. For 8 year old children the mean of total word legibility is 81.86 , for letter 84.10 , and for numeral 93.48. For 9 year old children the mean of total word legibility is 83.8 , for letter 83.51 and for numeral 93.25.

When age-wise analysis was done, it was seen that at 6 year of age. 10-12 letters on an average are legible in lower case and uppercase letters. In this age most of the children are having handwriting issues like jumping of letters, spacing between two letters is either more or less, reversing the letters such as b, $d$, $\mathbf{s , ~} \mathbf{h}, \mathbf{p}, \mathbf{z}$ is commonly seen. As per observations made during assessment, they appeared to be easily distracted, as they gave decreased eye contact and attention while performing these tasks. It was also observed that some children were not holding the pencil properly leading to lot of adjustments every now and then. It is likely that children have just started to write formally at this age and development of handwriting is in its formative stage. The reasons for various difficulties in handwriting of present study match with the research by Graham S, et.al in 2001. They described the illegibility at each grade level and defined it as "difficult". They described their study at the $1^{\text {st }}$ grade level; four out of every letters of the alphabet were legible in lowercase manuscript letters. Ninety percent of first graders were having difficulty in making letter s, e and c. Slightly more difficult letters were $\mathrm{o}, \mathrm{v}, \mathrm{x}, \mathrm{i}, \mathrm{m}, \mathrm{w}, \mathrm{p}, \mathrm{f}$ and $\mathrm{r}$. Even further more difficult letters were $\mathrm{q}, \mathrm{z}, \mathrm{g}, \mathrm{u}, \mathrm{n}, \mathrm{k}, \mathrm{j}$ and $\mathrm{y}$.

At 7 year of age, in present study. In this age group there were less handwriting difficulties as compared to 6 years old. In this age group the more handwriting difficulties was they using eraser excessively while performing the task. They wrote uppercase letter instead of lower case letter. According to observations, some reason may be for this handwriting difficulty was poor attention in task, distracted easily, unable to read words and letters, eye hand coordination etc.

At 8 year of age, in present study the performance of this age was less than 7 and 9 year age groups. They have more handwriting difficulties than other groupslike in age 6, 7 and 9. They have difficulties in numeral writing, dictation, near point copying and far point copying. The most common handwriting difficulties was they wrote in cursive instead of manuscript, letter formation is affected, alignment was improper, asking doubt again and again for erasing letters, spacing affected, difficulties in confusing in $\mathrm{w}$ or $\mathrm{m}$ in' cows' word, not able read properly from far point copying, the letters are illegible - According to observations, some reason for these handwriting difficulties was poor attention in task, distracted easily, unable to read words and letters, eye hand coordination and learning the new script that is cursive script freshly, adding confusion between cursive and manuscript/ what to write cursive or manuscript? And one more reason was improper sitting posture while doing this task.

At 9 year of age, in present study, the handwriting difficulties of this age group was writing in cursive, spelling mistakes, reverse letters, improper alignment, not listening to instructions carefully, able to write sentence but not able to make proper sentence. Spelling mistake was there in sentence composition task. Their sitting posture of child was also affected. According to observations, it appeared that children were not listening to instructions carefully; the attitude towards examiner was not serious, while some children showed anxiety and fear from doing tasks. 


\section{EPRA International Journal of Research and Development (IJRD)}

Volume: 6 | Issue: 9 | September 2021
- Peer Reviewed Journal
Mostly 6 year of children the grasping pattern is difficult because of new learning activities like handwriting they hold the pencil improperly. The results support various study that pencil grasp does not have significant effect on handwriting legibility. Similar observation was found while conducting the study. ${ }^{(5)}$

Most of the children were not sitting properly while doing handwriting task. The position of children was mostly forward bending, the responsive booklet was kept tilted improperly, the hand position was improper. Rosenblum S, Goldstand S, Parush S, define biomechanical ergonomic factors related to nonproficient and proficient hand writers. Study has found significant difference with respect to all biomechanical ergonomic factors measured (i.e. body positioning, pencil grasp, pencil positioning and consistency of pencil grip). ${ }^{(6)}$

As seen in Table no.5 the mean of total legibility score of word in English medium children is 83.567 and for non- English medium the score is 80.929. Total word legibility score of English medium is similar to the Non-English medium (vernacular) and is not significant in difference. The mean of total legibility score of letters is 86.671 and for non- English medium is 81.189 . Here, the English medium children have performed better than Non-English medium children and there is significant difference in the means. Lastly, the mean of total legibility of numeral is 97.077 and for non- English medium is 90.159. Here too, the English medium children have performed better than NonEnglish medium as the difference in mean is statistically significant. Therefore, it appears that the handwriting legibility of letter and numeral are better in English medium children than their counterparts. In whole of Asia, English is very important part in academic and it is widely in used in various countries. In India, English has been taught as a compulsory subject. In spite of this most of the students have difficulty in speaking in English and writing in English because of lack of practice. The reason of handwriting illegibility stated by Graham $\mathrm{S}$ et.alfound that the legibility of children's handwriting was improving ingrades $1^{\text {st }}$ to $4^{\text {th }}$ of elementary schools and the handwriting legibility declined in grades 7 through $9 .{ }^{(7)}$

When a writer is able to write in more than one script, as in the present study, the writer is usually more skilled in the first learnt script, i.e., the mother tongue. Singh et al. (1994) described on their study that a writer may have influence of the vernacular characteristics of primary language (used commonly in their daily life) and idiosyncratic features on their secondary language.
In this study, most of the children are from deprived background. According to observation, the parents did not concentrate properly on their child due to deprived background and some parents are not educated and came from village. Most of the children, who were taken, were siblings of disabled child and the parents concentrated on disabled child. The one more reasons of poor academic skills was described by Saraswati C. Hushal and V. Gaonkar in their study, $50 \%$ of institutional children were poor in academic skills such as reading, writing and arithmetic skills. The reason for poor skills is most of the children were from deprived background. Several conditions such as parental lack of stimulation, lack of early school, parental deprivation etc. ${ }^{(9)}$

\section{CONCLUSION}

From the above result we concluded that:

$\square$ ETCH is a handwriting tool which can distinguish handwriting legibility of children with English medium with handwriting of non- English medium children as their performances varied significantly in manuscript version.

\section{LIMITATIONS}

- The study design did not compare cursive handwriting skills in both groups' i.e. English and non-English medium schools.

- Speed of handwriting was not considered in the analysis.

\section{RECOMMENDATIONS}

- Further study on children with disability from English and non-English medium should be done having ETCH-M.

- Also ETCH-C (cursive) version should be need to analyse performance of children in English and non- English medium.

\section{REFERENCES}

1. Schwellnus H, Cameron D, Carnahan H. Which to Choose: Manuscript or Cursive Handwriting? A Review of the Literature. J Occup Ther Sch Early Interv. 2012;5(3-4):248-58.

2. Gafoor K, A. R. N. Development of Malayalam Handwriting Scale for School Students in Kerala. Guru J Behav Soc Sci. 2015 Jun;3:388-95.

3. Clark GJ. The relationship between handwriting, reading, fine motor and visual-motor skills in kindergarteners. Diss Abstr Int Sect A Humanit Soc Sci [Internet]. 2011;71(9-A):3137.

4. Smith JC. Occupational Therapy for Children. 6th editio. Mosby Elsevier; 2010. 555-582 p.

5. Cornhill H. Factors that relate to good and poor 


\section{EPRA International Journal of Research and Development (IJRD)}

Volume: 6 | Issue: 9 | September 2021

handwriting. Am J Occup Ther. 1996;50(9):737-9.

6. Rosenblum S, Goldstand S, Parush S. Relationships among biomechanical ergonomic factors, handwriting product quality, handwriting efficiency, and computerized handwriting process measures in children with and without handwriting difficulties. Am J Occup Ther. 2006;60(1):28-39.

7. Sayeed I. Error analysis in writing: a comparative study of Bangla medium and English medium schools in Dhaka [Thesis]. BRAC University; 2016.

8. No A, Science F, Geqd F, Science F, Government $S$, Science F. Interscript comparison of handwriting features leading to their identification and authorship. 2017;(3784).

9. Saraswati C. Hunshal. Impact of intervention on learning abilities of institutional children. Educ Res Rev. 2012;7(9):82-8. 